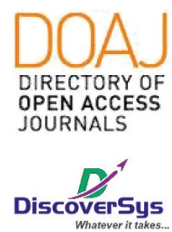

Published by DiscoverSys

\title{
Hubungan antara Chronic Kidney Disease (CKD) dengan hipotiroid di RSUP Dr. Kariadi Semarang, Indonesia
}

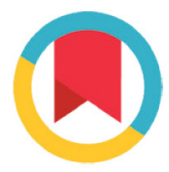

CrossMark

\author{
I Gede Ardy Surya Dharmanta ${ }^{1 *}$, Indranila Kustarini Samsuria ${ }^{2}$
}

\section{ABSTRACT}

Background: Thyroid hormone in many previous studies have been linked to chronic kidney disease (CKD). There are several interactions between renal dysfunction and thyroid hormones that influence each other. The aim of this study was to see the effect of CKD on the thyroid.

Methods: Cross sectional studies on subject data taken retrospectively by looking at medical records on a single center Dr. Kariadi Semarang Hospital during the period 1 June 2017 - 1 June 2018 to then observe the correlation effect of CKD on thyroid hormones by comparing serum urea and creatinine with $\mathrm{T} 3, \mathrm{~T} 4$ and
TSH.

Results: There was a significant correlation of CKD on T3 and TSH levels with ureum $(p=0.020$ and $p=0,0,25)$, and there was a significantly weak correltaion with creatinin $(p=0,081)$, but there was no significant correlation in $\mathrm{T} 4(\mathrm{p}=0,102 ; p=0,108)$.

Conclusion: The results of this study can be concluded that there is a significant correlation between Chronic Kidney Disease (CKD and hypothyroidism, especially the correltation effect of $\mathrm{T} 3$ with ureum and creatinine, and TSH with ureum.

Keywords: Hypothyroid, Chronic Kidney Disease, renal function, thyroid hormone

Cite This Article: Dharmanta, I.G.A.S., Samsuria, I.K. 2019. Hubungan antara Chronic Kidney Disease (CKD) dengan hipotiroid di RSUP Dr. Kariadi Semarang, Indonesia. Intisari Sains Medis 10 (1):256-259. D01: 10.1556/ism.v10i1.353

\section{ABSTRAK}

Latar belakang: Hormon tiroid pada penelitian - penelitian sebelumnya telah banyak yang dihubungkan dengan chronic kidney disease (CKD). Terdapat beberapa interaksi antara disfungsi ginjal dan hormon tiroid yang saling mempengaruhi. Tujuan penelitian ini adalah melihat pengaruh CKD pada tiroid.

Metode: Penelitian belah lintang pada data subjek yang diambil secara retrospektif dengan melihat rekam medik pada senter tunggal di RSUP Dr. Kariadi Semarang selama periode 1 Juni 2017 1 Juni 2018 untuk kemudian dilihat hubungan pengaruh CKD pada hormon tiroid dengan membandingkan antara serum ureum dan kreatinin dengan T3,T4 dan TSH.

Hasil: Terdapat pengaruh signifikan CKD pada T3 dan TSH dengan ureum ( $p=0,020$ dan $p=0,025)$ dan pada TSH hubungan signifikan lemah dengan kreatinin $(p=0,081)$, tetapi pada T4 tidak terdapat hubungan yang signifikan dengan ureum dan kreatinin $(p=0,102$; $p=0,108)$.

Simpulan: Dari hasil penelitian dapat disimpulkan bahwa terdapat hubungan yang bermakna antara Chronic Kidney Disease (CKD dan hipotiroid, terutama pada pengaruh T3 dengan ureum dan kreatinin, dan TSH dengan ureum.

Kata Kunci: Hipotiroid, Chronic Kidney Disease, renal function, hormon tiroid

Site Pasal Ini: Dharmanta, I.G.A.S., Samsuria, I.K. 2019. Hubungan antara Chronic Kidney Disease (CKD) dengan hipotiroid di RSUP Dr. Kariadi Semarang, Indonesia. Intisari Sains Medis 10 (1): 256-259. D0I: 10.1556/ism.v10i1.353

\section{*Korespondensi:}

I Gede Ardy Surya Dharmanta; PPDS-1 Patologi Klinik, Fakultas Kedokteran, Universitas Diponegoro, Semarang, Indonesia; ardysurya@gmail.com
Diterima :12-11-2018

Disetujui :04-02-2019

Diterbitkan: 01-04-2019

\section{PENDAHULUAN}

Chronic Kidney Disease (CKD) adalah penyakit yang memiliki karakteristik hilangnya fungsi ginjal dalam periode tertentu. Penyakit ini bermanifestasi dalam bentuk menurunnya fungsi ginjal selama lebih dari tiga bulan, dan ditentukan dengan mengukur perkiraan laju filtrasi glomerulus (eGFR). ${ }^{1}$ CKD merupakan penyakit progresif dan merupakan kondisi yang ireversibel dan merupakan penyakit penyebab kematian ke 8 di Amerika Serikat. $^{2}$ Di Indonesia sendiri prevalensinya berdasarkan diagnosis dokter, prevalensinya tertinggi di Sulawesi Tengah sebesar 0,5\%, diikuti Aceh, Gorontalo, dan Sulawesi Utara masing masing 0,4\%. Nusa Tenggara Timur, Sulawesi Selatan, Lampung, Jawa Barat, Jawa Tengah, D.I. Yogyakarta dan Jawa Timur masing - masing $0,3 \%{ }^{3}$

Hipotiroid adalah salah satu dari banyak komplikasi yang ditemukan pada pasien 
dengan gagal ginjal kronik, selain komplikasi kardiovaskular. ${ }^{4,5}$ Penelitian - penelitian sebelumnya melaporkan bahwa hipotiroid dapat disebabkan oleh mekanisme seperti penurunan cardiac output ${ }^{6}$, peningkatan resistensi vaskular ${ }^{7}$, dan peningkatan kadar serum kreatinin yang disebabkan oleh myopati atau rabdomiolisis. ${ }^{8}$

Hipotiroid juga dilaporkan berhubungan dengan aterosklerosis karotis, yang mana merupakan resiko yang paling berat dari CKD. ${ }^{9}$ Beberapa penelitian telah mengevaluasi pengaruh dari aterosklerosis karotis dalam hubungannya antara hipotiroid dan disfungsi renal. ${ }^{10}$

Tujuan dari penelitian ini adalah melihat apakah terdapat pengaruh antara penyakit ginjal kronik (CKD) pada pengaruhnya terhadap munculnya hiportiroid.

\section{METODE PENELITIAN}

Penelitian ini merupakan penelitian belah lintang (cross sectional) yang dilakukan di Laboratorium RSUP Dr. Kariadi Semarang. Data penelitian diambil dari rekam medis pasien yang dirawat di RSUP Dr. Kariadi Semarang selama periode 1 Juni 2017 hingga 1 Juni 2018.

Populasi sampel yang memenuhi kriteria inklusi dapat diikutkan kedalam penelitian adalah pasien dengan diagnosa CKD yang memiliki komplikasi hipotiroid, dan kriteria eksklusi adalah populasi sampel dengan diagnosa CKD namun memiliki

Tabel 1. Karakteristik data subyek penelitian

\begin{tabular}{lcc}
\hline \multicolumn{1}{c}{ Variabel } & N & $\%$ \\
\hline Usia & & \\
$\leq 45$ tahun & 13 & 32,5 \\
$\geq 45$ tahun & 27 & 67,5 \\
Jenis Kelamin & & \\
Laki - laki & 17 & 42,5 \\
Perempuan & 23 & 57,5 \\
\hline
\end{tabular}

Tabel 2. Deskriptif TSH, T3, T4, Ureum, Kreatinin dan Uji Normalitas data Shapiro-Wilk

\begin{tabular}{ccccc}
\hline Variabel & Mean \pm SD & Median $(\min -\mathbf{m a x})$ & $\mathbf{P}$ \\
\cline { 1 - 2 } \cline { 4 - 4 } TSH & $20,66 \pm 16,16$ & $20(0,01-66,89)$ & $<0,001$ \\
T3 & $0,85 \pm 0,38$ & $0,8(0,33-1,77)$ & 0,007 \\
T4 & $12,32 \pm 13,33$ & $8,9(2,35-73,85)$ & 0,000 \\
Ureum & $90,88 \pm 56,25$ & $98(10-215)$ & 0,029 \\
Kreatinin & $7,40 \pm 5,64$ & $8,25(0,5-17,8)$ & 0,002 \\
\hline
\end{tabular}

penyakit tiroid lain seperti keganasan kelenjar tiroid tidak dimasukkan kedalam sampel populasi penelitian. Metode pemeriksaan laboratorium T3,T4, TSH menggunakan metode Enzyme- linked immunosorbent assay (ELISA). Pada pemeriksaan ureum dan kreatinin menggunakan metoda enzimatik dengan automatic analyzer.

Data diolah menggunakan program komputer SPSS Statistic IBM Ver.23. Dilakukan uji normalitas dengan Saphiro-Wilk karena besar sampel masingmasing kelompok kurang dari 50. Data yang terdistribusi normal dianalisis uji parametrik menggunakan uji beda $t$ tidak berpasangan. Data yang terdistribusi tidak normal setelah dilakukan transformasi atau syarat uji $\mathrm{t}$ tidak berpasangan tidak terpenuhi dianalisis dengan uji Saphiro-Wilk. Uji statistik dianggap bermakna jika $p<0,05$.

Penelitian dilakukan di RSUP dr.Kariadi setelah mendapatkan persetujuan etik (ethical clearance) dari Komisi Etik Penelitian Kesehatan dengan nomor 023/EC/KEPK-RSDK-2018.

\section{HASIL DAN PEMBAHASAN}

Data pasien sejumlah 67 sehingga didapatkan jumlah data subjek sebanyak 40 dengan memilah berdasarkan kriteria eksklusi dan inklusi. Data subjek yang tidak dimasukkan atau di eksklusi adalah pasien dengan kemoterapi atau sedang menjalani terapi radiasi.

Jumlah data subjek laki - laki sebanyak 17 $(42,5 \%)$ dan perempuan sebanyak $23(57,5 \%)$ dan usia subjek sebagian besar berusia 45 tahun atau lebih (67,5\%). (Tabel 1)

Pada Tabel 2 menyajikan analisis uji normalitas data Saphiro-Wilks, yang mana menunjukkan kalau distribusi data pada TSH, T3, T4, Ureum dan Kreatinin subjek tidak terdistribusi normal.

Pada Tabel 3 menunjukkan uji korelasi signifikan antara T3 terhadap ureum $(\mathrm{p}=0,020)$ dan kreatinin $(\mathrm{p}=0,011)$, yang mana ini menandakan adanya pengaruh penurunan T3 terhadap efeknya pada Ureum dan Kreatinin. Sementara pada uji koefisien korelasi Spearman's lemah antara T3 dengan Ureum $(\mathrm{r}=-0,366)$ dan Kreatinin $(\mathrm{r}=-0,397)$ menunjukkan koefisien yang negatif, dimana peningkatan T3 disertai penurunan ureum.

Pada Tabel 3 juga uji korelasi antara T4 dengan Ureum $(p=0,102)$ dan Kreatinin $(p=0,108)$ tidak menunjukkan hasil yang signifikan bermakna. TSH juga tidak menunjukkan hubungan yang signifikan dengan Kreatinin $(\mathrm{p}=0,081)$, tetapi menunjukkan hubungan yang signifikan positif lemah dengan ureum $(\mathrm{p}=0,025)$.

Dari hasil penelitian ini menunjukkan terdapat hubungan korelasi negatif lemah yang bermakna antara T3 dengan ureum dan kreatinin. Penelitian 
Tabel 3. Uji Korelasi Spearman's T3,T4 dan TSH terhadap Ureum Kreatinin

\begin{tabular}{ccccccccc}
\hline \multirow{2}{*}{ Variabel } & $\mathbf{n}$ & \multicolumn{2}{c}{$\mathbf{T}_{\mathbf{3}}$} & \multicolumn{2}{c}{$\mathbf{T}_{\mathbf{4}}$} & \multicolumn{2}{c}{ TSH } \\
\cline { 3 - 8 } & & $\mathbf{p}$ & $\mathbf{r}$ & $\mathbf{p}$ & $\mathbf{r}$ & $\mathbf{P}$ & $\mathbf{R}$ \\
\hline \multirow{2}{*}{ Ureum } & \multirow{2}{*}{40} & $0,020^{*}$ & $-0,366$ & 0,102 & $-0,263$ & $0,025^{*}$ & 0,354 \\
Kreatinin & & $0,011^{*}$ & $-0,397$ & 0,108 & $-0,258$ & 0,081 & 0,279 \\
\hline
\end{tabular}

${ }^{*}$ Signifikan $(\mathrm{p}<0,05)$

\section{KONFLIK KEPENTINGAN.}

Pada penelitian ini peneliti tidak memiliki konflik kepentingan dengan pihak manapun dalam melakukan penelitian.

\section{PENDANAAN PENELITIAN.}

Semua biaya penelitian ditanggung oleh biaya mandiri.

\section{AUTHOR CONTRIBUTION}

Basu dan Mohapatra menyebutkan gangguan pada T3 pada pasien dengan CKD dikarenakan kondisi uremia dapat menggantikan keterikatan T3 dan juga T4 pada reseptor - reseptor protein pengikat. ${ }^{11}$

Demikian juga dengan TSH yang memiliki hubungan dengan ureum. Pada penelitian oleh Basu G et al dan Singh PA et al, terdapat hubungan antara TSH dengan CKD, yang mana peningkatan angka TSH sering terjadi pada CKD, walaupun perubahannya tidak signifikan ${ }^{12}$. Penelitian lain oleh Kannan A et al menyebutkan TSH juga tidak berbanding lurus dengan derajat keparahan CKD. ${ }^{13}$

Chronic Kidney Disease (CKD) mempengaruhi axis hipotalamus - glandula pituitari - kelenjar tiroid dalam metabolisme hormon tiroid. Dan pada pemeriksaan laboratorium yang paling umum ditemukan adalah rendahnya kadar T3 pada pasien CKD. ${ }^{13,14}$

Rendahnya kadar T3 pada pasien CKD dapat terjadi karena puasa, metabolik kronik yang menyebabkan asidosis, dan malnutrisi protein kronis yang umumnya sering terlihat pada CKD, yang mana dapat mempengaruhi pengikatan transport T3. ${ }^{14,15}$ Kadar T3 yang rendah juga dapat terjadi pada proses metabolisme ekstra tiroid seperti pada proses konversi dari T4 menjadi T3 karena penurunan klirens sitokinin inflamatorik seperti TNF-alfa dan IL-1, yang mana fungsi dari sitokinin ini adalah menginhibisi / menghambat ekspresi 1,5-deiodinase yang membantu mengkonversi T4 menjadi T3. ${ }^{15,16}$

\section{SIMPULAN DAN SARAN}

Dari hasil penelitian dapat disimpulkan bahwa terdapat hubungan yang bermakna antara Chronic Kidney Disease (CKD) dan hipotiroid, dimana terutama hubungan terdapat pada pengaruh T3 dengan ureum dan kreatinin dan TSH dengan ureum.

Perlu dilakukan penelitian lebih lanjut untuk melihat dengan lebih jelas pengaruh CKD terhadap tiroid, terutama diperlukan penelitian dengan jumlah sampel yang lebih besar.
I Gede Ardy Surya D. melakukan desain penelitian, pengambilan data, analisis penelitian, menulis penelitian, bersama Indranila K.S. melaksanakan editing, melakukan dan mengirimkan naskah hingga terbitnya tulisan ini .

\section{DAFTAR PUSTAKA}

1. Aryee NA, Tagoe EA, Anomah V, Arko-Boham B, Adjei DN. Thyroid hormone status in Ghanaian patients with chronic kidney disease. Pan Afr Med. J . 2018; 29 (1):137143.

2. Melonie Heron. [Internet] "Centers for Disease Control and Prevention," Leading Causes of Death, 2018 July 26, [updated 2018 feb 11; cited 2018 Sept 19] from : http:// www.cdc.gov/nchs/fastats/lcod.htm.

3. Riskesdas.Badan Penelitian dan Pengembangan Kesehatan Kementrian RI. Riset kesehatan dasar. Jakarta : 2013:83-97.

4. Klein I and Ojamaa K: Thyroid hormone and the cardiovascular system. N Engl J Med, 2001; 344(7): 501509

5. Villabona C, Sahun M, Gomez N, Gomez JM, Soler J, Roca $\mathrm{M}$ et al. Blood volumes and renal function in overt and subclinical primary hypothyroidism. Am J Med Sci, 1999; 318 (4): 277-280.

6. Khaleeli AA, Griffith DG and Edwards RHT. The clinical presentation of hypothyroid myopathy and its relationship to abnormalities in structure and function of skeletal muscle. Clin Endocrinol, 1983; 19(3): 365-376

7. Peixoto MEJ, Bittencourt MS, Pereira AC, Goulart AC, Santos IS, Lotufo PA et al. Subclinical hypothyroidism is associated with higher carotid intima-media thickness in cross-sectional analysis of the Brazilian Longitudinal Study of Adult Health (ELSA-Brasil). Nutr Metab Cardiovasc Dis. 2016; 26(10): 915-921.

8. Zhou Y, Zhao L, Wang T, Hong J, Zhang J, Xu B et al. Free triiodothyronine concentrations are inversely associated with elevated carotid intima-media thickness in middleaged and elderly chinese population. J Atheroscler Thromb, 2016; 23(2): 216-224.

9. Shimizu M, Furusyo N, Mitsumoto F, Takayama K, Ura $\mathrm{K}$, Hiramine $\mathrm{S}$ et al. Sub clinical carotid atherosclerosis and triglycerides predict the incidence of chronic kidney disease in the Japanese general population: Results from the Kyushu and Okinawa Population Study (KOPS). Atherosclerosis, 2015; 238(2): 207- 212

10. Nambi V, Chambless L, Folsom AR, He M, Hu Y, Mosley $\mathrm{T}$ et al. Carotid intima-media thickness and presence or absence of plaque improves prediction of coronary heart disease risk in the atherosclerosis risk in communities (ARIC) study. J Am Coll Cardiol, 2010; 55(15): 1600-1607. 
11. Basu $G$ and Mohapatra A. Interactions between thyroid disorders and kidney disease. Indian J Endocr Metab 2012;16(2): 204-213.

12 Singh PA, Bobby Z, Selvaraj N, Vinayagamoorthi R. An evaluation of thyroid hormone status and oxidative stress in undialyzed chronic renal failure patients. Indian J Physiol Pharmacol. 2006;50(3):279-284.

13 Kannan A, Sriramakrishnan V, Kannan B, Anandan H. Thyroid function abnormalities in patients with chronic kidney disease - A prospective study. Int J of Scientific study 2017; 5(4):68-72.

14. Lim VS, Fang VS, Katz AI, and Refetoff S. Thyroid dysfunction in chronic renal failure. A study of the pituitary-thyroid axis and peripheral turnover kinetics of thyroxine and triiodothyronine. J Clin Invest 1977;60(3): 522-534.
15. Wiederkehr MR, Kalogiros J and Krapf R. Correction of metabolic acidosis improves thyroid and growth hormone axes in haemodialysis patients. Nephrol Dial Transplant. 2004;19(5):1190-1197.

16. Zoccali C, Tripepi G, Cutrupi S, Pizzini P and Mallamaci F. Low triiodothyronine: A new facet of inflammation in endstage renal disease. J Am Soc Nephrol. 2005;16(9):27892795 .

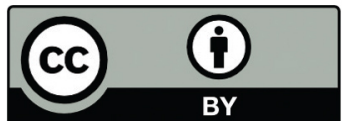

This work is licensed under a Creative Commons Attribution 